\title{
Alkaline protease production by solid state fermentation of mustard oil cake
}

\author{
Namrata Sharma \\ Deptt. Of Biochemistry. Mata Gujri Mahila Mahavidyalaya, Jabalpur (M.P.), India
}

\begin{abstract}
Mustard oil cake being rich in protein offer potential benefits when utilized as substrate for fermentative production of enzymes. In the present study impact of diluents on the production of protease by A.terreus grown on mustard oil cake was done. Supplementation of $D_{3}$ diluent increase the enzyme production significantly (110 U/g of dry solids). Enzyme production was maximum when mustard oil cakes inoculated with A.terreus was incubated at $40^{\circ} \mathrm{C}$ temperature \& $9.5 \mathrm{pH}$. Maximum protease production was obtained after $96 \mathrm{~h}$ of incubation period.
\end{abstract}

Keywords-Alkaline protease, A.terreus, Mustard Oil cake, SSF.

\section{INTRODUCTION}

Protease is one of the most important commercial enzymes, and is used in food processing, detergents, dairy industry and leather making [1]. Although proteases are found ubiquitously in plants, animals and microorganisms, the later are the preferred sources of proteases and dominated the commercial application. Fungi exhibit a wide variety of proteases than bacteria. Furthermore fungi are generally regarded as safe strains and they produce extracellular enzymes, which are easier to be recovered from fermentation broth [2]. The microbial proteases of Aspergillus species, in particular, have been studied in detail since they are known for their capacity to secrete high levels of enzymes in their growth environment.

Oil cakes are by-products obtained after oil extraction from the seeds. There are several reports describing production of various enzymes using oil cakes as substrate in solid state fermentation (SSF). Oil cakes are ideally suited nutrient support in SSF rendering both carbon and nitrogen sources, and reported to be good substrate for enzyme production using fungal speices [3]. Sandhya et al., [2] and Sumantha et al., [4] have reported protease production using oil cakes as nutrient source.

Mustard oil cake (MOC) has protein content of about 38.5\% and fiber content of 3.5\% [5]. Amino acid profile of MOC shows them to be rich in leucine, phenylalanine, arginine and glycine [6].

This work reports on the use of mustard oil cakes for producing proteases of Aspergillus terreus by solid-state fermentation.

\section{MATERIAL AND METHODS}

2.1 Microorganism and maintenance of culture -

Aspergillus terreus JBPSI- 2 used in this study was isolated from soil samples in Jabalpur area and was identified on the basis of molecular analysis by Agharkar Research Institute, Pune (MH). The fungus was grown and maintained on potato dextrose agar (PDA) slants at $28 \pm 2^{\circ} \mathrm{C}$ with fortnightly transfer to fresh medium.

2.2 Substrate -

Mustard oil cake used in this study was obtained from local market in Jabalpur, M.P. India.

2.3 Inoculum preparation

The inoculum was prepared by dispersing the spores from a week old fungal slant culture in $0.1 \%$ Tween- 80 solution with a sterile inoculum loop.

\subsection{Solid state fermentation}

Five grams of mustard oil cake was taken in a $250 \mathrm{ml}$ Erlenmeyer flask moistened with $5 \mathrm{ml}$ of diluent, sterilized at $121^{\circ} \mathrm{C}$ for $15 \mathrm{~min}$, cooled inoculated with $1 \mathrm{ml}$ of fungal spore suspension and incubated at $28 \pm 2^{\circ} \mathrm{C}$ for $96 \mathrm{~h}$ unless otherwise specified. All experiments were carried out in two sets. The results shown are average value $\pm \mathrm{SD}$.

2.5 Impact of diluents on protease production following eight diluents (pH adjusted to 8.5) were used to moistened the substrate [7]

$\mathrm{D}_{1}:(\% \mathrm{~W} / \mathrm{V})$ Peptone, 1.0 dextrose 4.0

$\mathrm{D}_{2}:(\% \mathrm{~W} / \mathrm{V}) \mathrm{NaNO}_{3}, 2.0 ; \mathrm{KH}_{2} \mathrm{PO}_{4}, 1.0 ; \mathrm{MgSO}_{4} .7 \mathrm{H}_{2} \mathrm{O}, 0.05 ; \mathrm{CaCl}_{2} .2 \mathrm{H}_{2} \mathrm{O}, 0.05 ; \mathrm{ZnSO}_{4} .7 \mathrm{H}_{2} \mathrm{O}, 0.01$ 
$\mathrm{D}_{3}:(\% \mathrm{~W} / \mathrm{V})$ Glucose, 7.0 ; Peptone, $2.0 ; \mathrm{KH}_{2} \mathrm{PO}_{4}, 0.4 ; \mathrm{MgSO}_{4} .7 \mathrm{H}_{2} \mathrm{O}, 0.05 ; \mathrm{CaCl}_{2} .2 \mathrm{H}_{2} \mathrm{O}, 0.05$; $\mathrm{ZnSO}_{4} \cdot \mathrm{H}_{2} \mathrm{O}, 0.01$

$\mathrm{D}_{4}:(\% \mathrm{~W} / \mathrm{V})$ Yeast extract, $1.0 ;$ Glucose, 3.3 ; Peptone, $1.0 ; \mathrm{CaCO}_{3}, 1.0$

$\mathrm{D}_{5}:(\% \mathrm{~W} / \mathrm{V})$ Glucose, 1.0 ; Peptone, 1.0 ; Beef extract, $1.5 ; \mathrm{NaCl}, 0.3$

$\mathrm{D}_{6}$ : (\%W/V) Glucose, 2.0; Peptone, $1.0 ;$ Beef extract, 1.0; $\mathrm{NaCl}, 0.3 ; \mathrm{CaCl}_{2}, 0.1 ; \mathrm{Na}_{2} \mathrm{CO}_{3}, 0.7$

$\mathrm{D}_{7}$ : (\%W/V) $\left(\mathrm{NH}_{4}\right)_{2} \mathrm{SO}_{4}, 1.4$; Urea, 3.0 $\mathrm{KH}_{2} \mathrm{PO}_{4}, 2.0 ; \mathrm{MgSO}_{4} .7 \mathrm{H}_{2} \mathrm{O}, 3.0 ; \mathrm{CaCl}_{2}, 3.0$

$\mathrm{D}_{8}$ : Distilled Water.

2.6 Optimization of process parameters -

Optimization of growth conditions and enzyme production was done using different parameters such as incubation time, $\mathrm{pH}$ and temperature.

\subsubsection{Incubation time -}

The effect of incubation period on enzyme production ( $\mathrm{pH} 8.5$; temperature $28 \pm 2{ }^{\circ} \mathrm{C}$ ) was investigated by checking the enzyme activity on $0,24 \mathrm{~h}, 48 \mathrm{~h}, 72 \mathrm{~h}, 96 \mathrm{~h}, 120 \mathrm{~h}, 144 \mathrm{~h}$ and $168 \mathrm{~h}$ of incubation.

\subsection{2 $\mathrm{pH}$ -}

The effect of $\mathrm{pH}$ on enzyme production was investigated by SSF in mustard oil cake by adjusting the $\mathrm{pH}$ of $\mathrm{D}_{3}$ diluent as the maximum enzyme production was obtained when this diluent was used as moistening agent. $\mathrm{pH}$ of the diluent was adjusted to 7, 7.5, 8, 8.5, 9, 9.5, 10, 10.5 and 11.0 using $1 \mathrm{M} \mathrm{NaOH}$. The substrates inoculated with A. terreus were then incubated for $96 \mathrm{~h}$ at $28 \pm 2^{\circ} \mathrm{C}$ as the maximum enzyme production was at the $96 \mathrm{~h}$ of incubation.

\subsubsection{Temperature -}

The favourable temperature for maximum protease production was studied with a range of $10^{\circ} \mathrm{C}$ to $65^{\circ} \mathrm{C}$. Substrate was moistened with $\mathrm{D}_{3}$ diluent $(\mathrm{pH}-9.5)$ and incubated for $96 \mathrm{~h}$ as the maximum enzyme production was obtained under these conditions.

\subsection{Enzyme extraction -}

A known quantity ( $5 \mathrm{~g}$ ) of the fermented material was mixed with $10 \mathrm{ml}$ of Tween $80(0.1 \%)$ solution in distilled water and homogenized by mixing in a rotary shakes at $150 \mathrm{rpm}$ for $1 \mathrm{~h}$. The solids were removed by filtration and filtrate were centrifuged at $8000 \mathrm{rpm}$ for $15 \mathrm{mins}$ at $4^{\circ} \mathrm{C}$. The resultant supernatant was used for analytical studies.

\subsection{Assay for protease activity -}

Protease activity was assayed by the method of Anson [8].

\section{RESULTS AND DISCUSSION}

\section{Impact of various diluents on protease production -}

Impact of various diluents on the production of protease by A.terreus grown on mustard oil cake as a substrate was done. In the present study the maximum enzyme production of $110 \mathrm{U} / \mathrm{g}$ of dry solids was observed when the substrate was moistened with $D_{3}$ diluent while minimum protease production was $(42 \mathrm{U} / \mathrm{g}$ of dry solids) obtained when moistened with $\mathrm{D}_{8}$ diluent i.e. distilled water. The ratio of substrate to diluent was kept 1:1. When substrate was moistened with glucose, peptone, $\mathrm{CaCl}_{2}, \mathrm{MgSO}_{4}, \mathrm{KH}_{2} \mathrm{PO}_{4}$ ( $\mathrm{D}_{3}$ diluent components), enzyme synthesis was maximum. It shows that organic nutrients (glucose, peptone) and inorganic nutrients $\left(\mathrm{CaCl}_{2}, \mathrm{ZnSO}_{4}, \mathrm{MgSO}_{4}\right)$ both stimulate the production of enzyme from A. terreus. Potassium dihydrogen phosphate in this diluent act as a constituent of the extraction buffer and may enhanced protease recovery from MOC.

\subsection{Optimization of process parameters -}

Any fermentation process is governed by a large number of physical, chemical and biological factors [4]. Fermentation time, temperature and $\mathrm{pH}$ are the parameters that impact largely on enzyme production.

\subsubsection{Incubation time -}

The time of incubation has an important role in cheaper commercial production of enzymes. Fig:1 shows that A. terreus gave the maximum yield of protease at $96 \mathrm{~h}$ of incubation in a SSF process with MOC as the substrate. The subsequent decrease in enzymes activity with increasing fermentation time could possibly be due to cessation of production by SSF [9].

\subsection{2pH -}

The influence of initial $\mathrm{pH}$ on production of protease by A.terreus was determined in the $\mathrm{pH}$ range of 711. Protease synthesis increased with increase of initial $\mathrm{pH}$ of the substrate and reached maximum at $\mathrm{pH} 9.5$; whereas below and above this level of $\mathrm{pH}$ yield was low (Fig:2). The $\mathrm{pH}$ dependent changes in the amount of enzyme production might have been due to $\mathrm{pH}$ dependent control of protease gene expression. The results clearly indicate the alkalophilic nature of the fungus. Similar studies on the influence of $\mathrm{pH}$ on protease production have been studied in different Aspergillus sp. In case of A.terreus the optimum $\mathrm{pH}$ was reported to be between 5.5 and $9.5[10]$. 


\subsubsection{Incubation temperature -}

SSF is more sensitive to temperature variation than broth culture, not only does the temperature regulates the synthesis of the enzyme but possibly the secretion of the enzyme by changing the properties of the cell wall [11]. The maximum protease activity was recorded at $40^{\circ} \mathrm{C}$. Increase in temperature resulted in considerable loss of activity, and poor or no growth. Aspergillus niger has been reported to produce maximum proteases at $40^{\circ} \mathrm{C}$, which is similar to that of our result [12]. An optimum temperature of $40^{\circ} \mathrm{C}$ for A.terreus has also been reported [13] which is similar to our study. Inactivation at higher temperatures may be attributed to incorrect conformation due to hydrolysis of the peptide chain, disruption of amino acids or aggregation.

\section{CONCLUSION}

In present study, the protease production capability of a native isolate of A.terreus JBPSI-2 from soil was exploited by SSF of mustard oil cake which is cheap and commonly available. The different parameters such as impact of various diluents, incubation time, $\mathrm{pH}$ and temperature were optimized. From the results it could be inferred that alkaline protease produced through solid state fermentation of the mustard oil cake by A.terreus JBPSI-2 could possibly find useful application in detergent industry.

\section{ACKNOWLEDGMENT}

The author is thankful to UGC, CRO Bhopal for financial support under the project (MS70/106045/11-12/CRO). The author is also thankful to Agharkar Research institute Pune, India for providing their services in molecular identification of fungal sample.

\section{REFERENCES}

1. Negi, S. and Banerjee, R., Optimization of cultural parameters to enhance production of amylase and protease from Aspergillus awamori in a single fermentation, African Journal of Biochemistry Research 4, 2010, 73-80.

2. Sandhya, C. Sumantha, A., Szakacs, G. and Pandey, A., Comparative evaluation of neutral protease production by Aspergillus oryzae in submerged and solid state fermentation, Biochemcial Process 40, 2005, 2689-2694.

3. Ramchandran, S. Singh, S. Larroche, C. Soccol, C.R. and Pandey, A. Oil cakes and their biotechnological application - A review, Bioresource. Technology 98, 2007, 2000-2009.

4. Sumantha, A. Sandhya, C. Szakacs, G. Soccol, C.R. Pandey, A., Production and partial purification of a neutral metalloprotease by fungal mixed substrate fermentation, Food Technol Biotechnol 43, 2005, 313-319.

5. Kuo, L.H., Animal feeding stuffs : compositional data of feeds and concentrates (part 3), Malaysian Agric. J. 46, 1967, 63-70.

6. Miller, R.W. Van Etlen, H. McGraw, C. Wolff, I.A., Jones, Q., Amino acid composition of seed meals from fortyone species of cruciferae, J.Agric. Food Chem. 10, 1962, 426-430.

7. IKram - Ul-Haq, Hamid, M. Sikandar, Auador, M.A., Production of protease by locally located mold culture under lab conditions, J.Biotechnol 21, 2003, 30-36

8. Anson, M.L., The estimation of pepsin, trypsin, papain and cathepsin with hemoglobin, J.Gen. Physiol 22, 1938, 79-89.

9. $\quad$ Pandey, A., Solid state fermentation, Biochem. Eng. 13, 2003, 81-84.

10. Chakrabarthi, S.K. Matsumura, N. and Ranu, R.S. Purification and Characterization of extracellular alkaline serine protease from Aspergillus terreus (IJIRA 6.2), Current Microbiology 40, 2000, $239-244$.

11. Satyanarayana, J., Production of bacterial extracellular enzymes by solid state fermentation (1), Wiley Eastern Ltd. New Delhi, 1994, 145-167.

12. Coral, G. Arikan, B. Unaldi, M.N. and Givenmes, H., Purification and characterization of a protease resistant cellulose from Aspergillus niger, Journal of Fermentation and Bio engineering, 39, 122-127.

13. Ali, U.F., Utilization of whey amended with some agro-industrial by-products for the improvement of protease production of Aspergillus terreus and its compability with commercial detergents, Research Journal of Agriculture and Biological Sciences 4 (6), 2008, 886-891. 
Table - 1: Impact of Various diluents on protease production by Aspergillus terreus in SSF using MOC as a substrate.

\begin{tabular}{|l|l|}
\hline Diluents & Protease activity $(\mathrm{U} / \mathrm{g}) \pm \mathrm{SD}$ \\
\hline $\mathrm{D}_{1}$ & $42 \pm 8$ \\
\hline $\mathrm{D}_{2}$ & $64 \pm 6$ \\
\hline $\mathrm{D}_{3}$ & $110 \pm 9$ \\
\hline $\mathrm{D}_{4}$ & $77 \pm 7$ \\
\hline $\mathrm{D}_{5}$ & $66 \pm 5$ \\
\hline $\mathrm{D}_{6}$ & $47 \pm 8$ \\
\hline $\mathrm{D}_{7}$ & $73 \pm 6$ \\
\hline $\mathrm{D}_{8}$ & $42 \pm 5$ \\
& \\
\hline
\end{tabular}

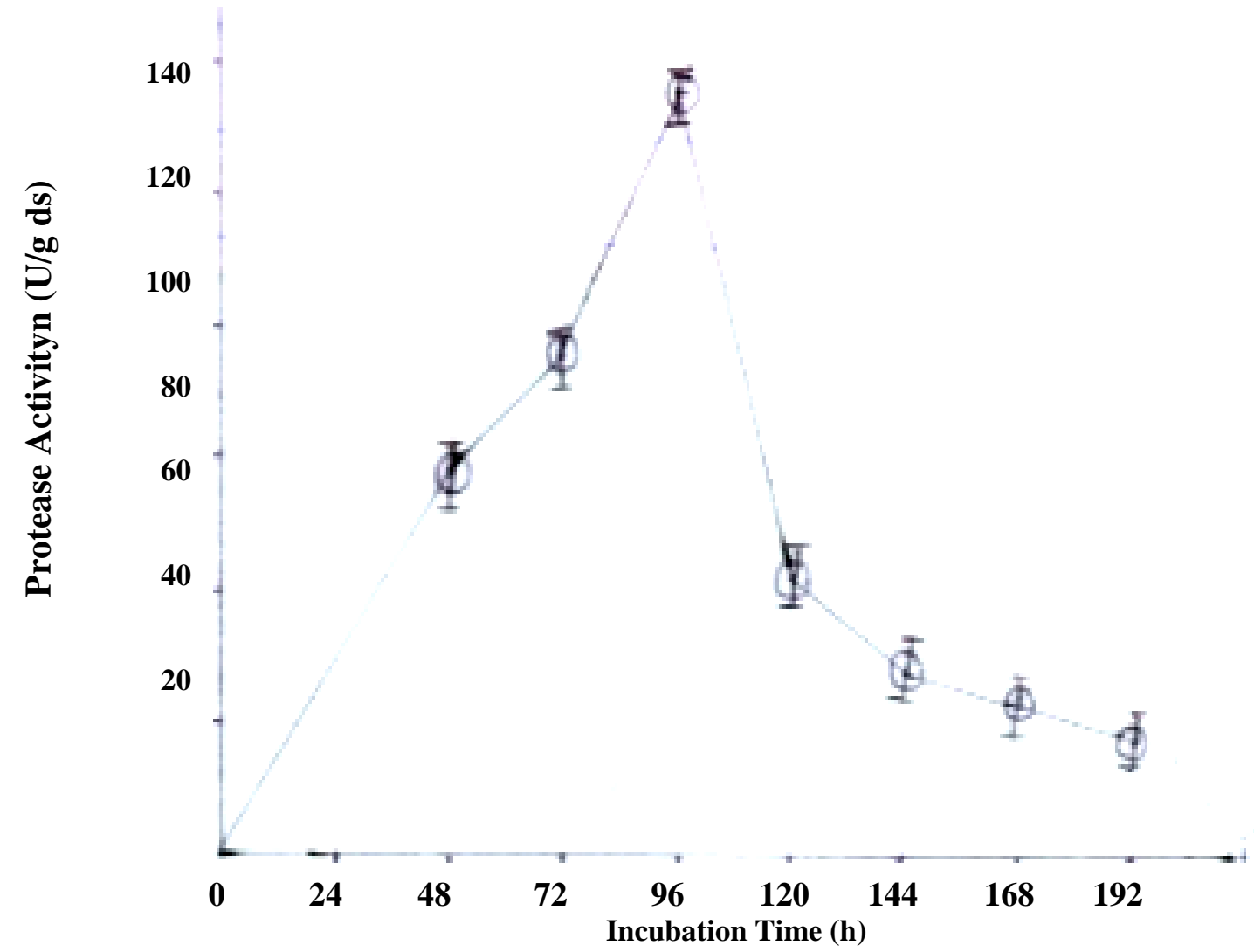

Figure-1: Protease activity by Aspergillus terreus in SSF using MOC as a substrate at different time of incubation. 


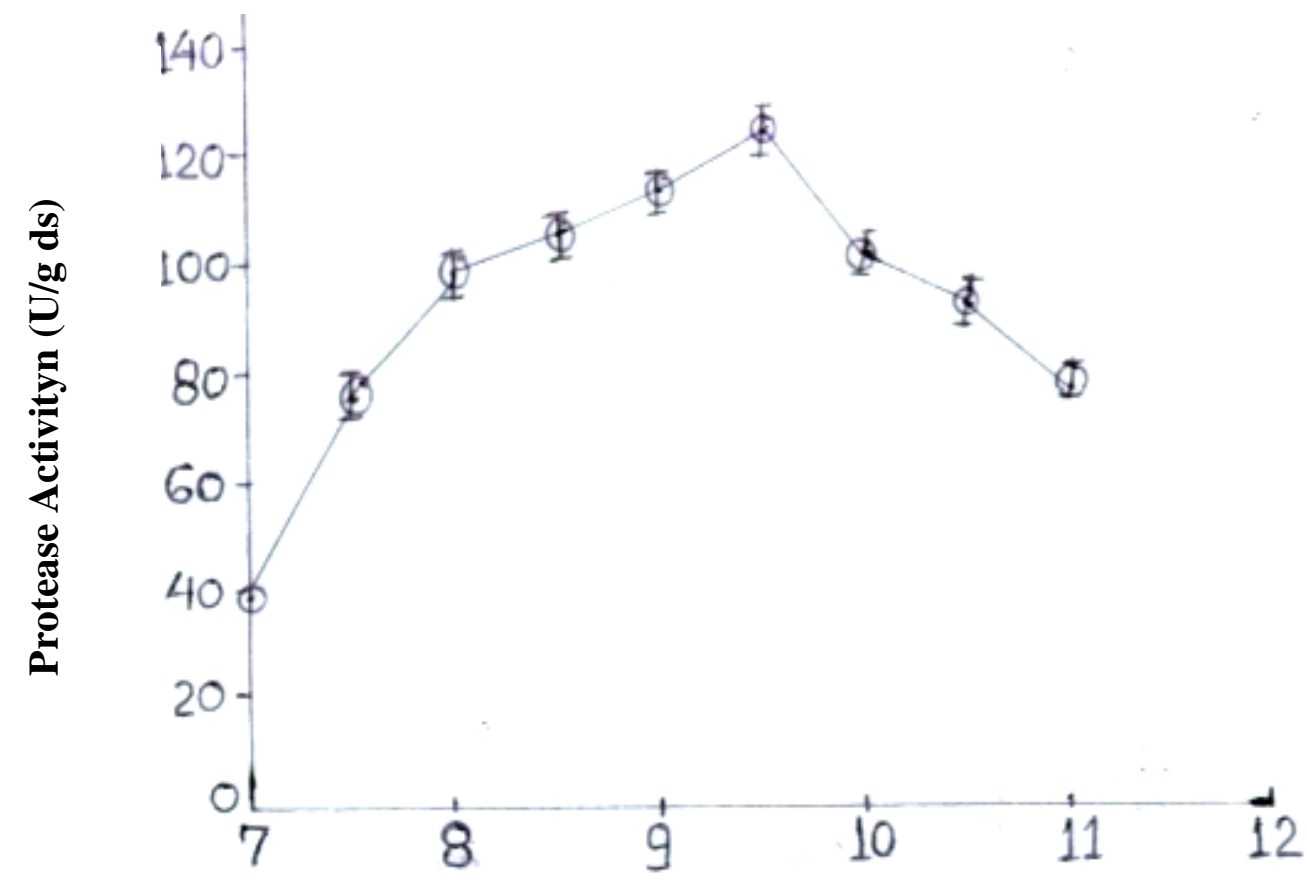

Figure- 2: Protease activity by Aspergillus terreus in SSF using MOC as a substrate at different $\mathrm{pH}$ 


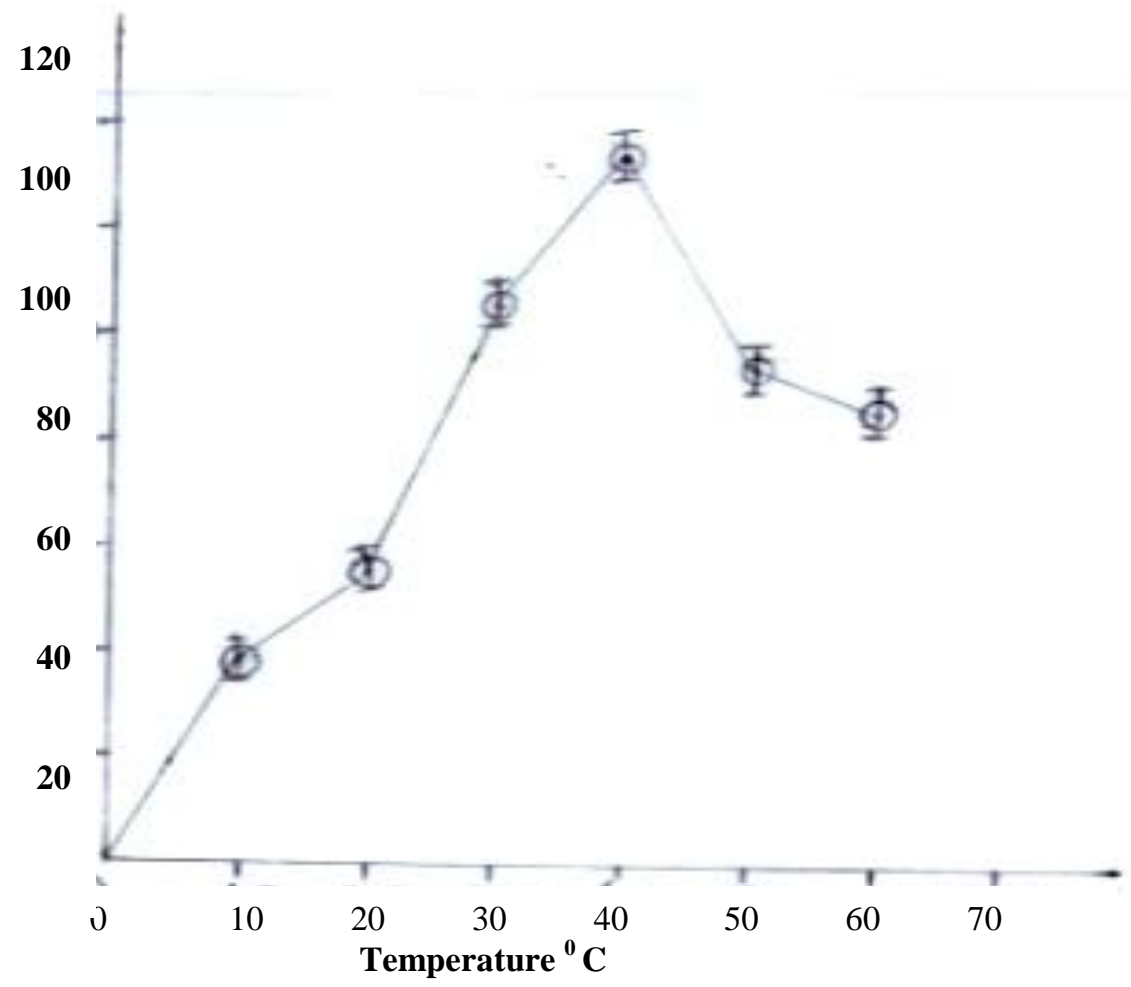

Figure- 3: Protease activity by Aspergillus terreus in SSF using MOC as a substrate at different temperatures. 